\title{
OBSERVATIONS ON THE REPRODUCTIVE PHEROMONES OF MICE
}

\author{
I. SOURCE \\ C. J. DOMINIC* \\ Physiological Laboratory, University of Cambridge \\ (Received 5th October 1965)

\begin{abstract}
Summary. Ovo-implantation is blocked in over $80 \%$ of newly mated female mice by exposing the females to fresh urine of alien (CBA) males. The same effect is also produced by topical application of male urine to the females three times a day. Pseudopregnancy induced by sterile mating is also blocked by exposure of the females to the fresh urine of alien males. Urine of alien males collected in a mixture of antibiotics and an antioxidant and stored for 1 to 7 days retains the pregnancyblocking capacity to a large extent.

The percentage of pregnancy failures in untreated controls is close to the percentage of spontaneous failure of pregnancy in undisturbed females. Hence it is concluded that urine is the immediate source of the pheromones produced by male mice which cause the failure of ovoimplantation in newly mated females.
\end{abstract}

\section{INTRODUCTION}

A block to ovo-implantation in newly mated mice caused by the proximity of males has been described by Bruce $(1959,1960)$. Early evidence suggested that the smell of the males was the operative factor in bringing about this failure of pregnancy. Subsequent investigations confirmed that the stimulus received by the female was olfactory in nature. Females from which the olfactory lobes were removed surgically no longer reacted to the presence of males (Bruce \& Parrott, 1960). Moreover, pregnancy was found to fail in normal females merely housed in soiled boxes recently vacated by males (Parkes \& Bruce, 1962). While ingestion is not entirely ruled out by these experiments, there is little doubt that the females were reacting to the smell the males left behind.

The success of the soiled boxes in preventing implantation suggested that male excreta in the box might be the source of the odour, but preparations of urine and faeces failed to reproduce the effect so that the source of the smell remained unknown.

The present series of experiments was designed with the object of locating the source of the male mouse reproductive pheromones which exert such a

* Present address: Department of Zoology, Banaras Hindu University, Varanasi 5, India. 
profound influence on female reproductive behaviour. A preliminary report of results of the investigations was presented at the Annual Conference of the Society for the Study of Fertility, at Oxford (Dominic, 1964).

\section{Mice}

\section{MATERIALS AND METHODS}

The females and all the stud males were albinos belonging to the Parkes $(\mathrm{P})$ strain maintained in this laboratory. The colony is closed and randomly bred. The test males and those used for the supply of urine belonged to the CBA strain which is known to have a high pregnancy-blocking capacity in respect of pregnancies initiated by $\mathrm{P}$ males in $\mathrm{P}$ females. The CBA males were mainly inbred, CBA/H, from the MRC Radiobiological Research Unit, Harwell or from the National Institute for Medical Research. Some were outbred and came from the Animal Supplies, London. No difference could be detected in the reaction of females to males from these three sources. They have not therefore been separately identified in reporting the results.

Test

Mated females were separated from the stud male when the vaginal plug was found (Day 0 ) and housed singly in boxes with sawdust bedding; $24 \mathrm{hr}$ later (Day 1 of pregnancy) they were transferred to boxes with cloth (white drill) bedding in the test situation. The females remained in the test situation for 3 days at the end of which time they were returned to their own original boxes with sawdust bedding.

TABLE 1

EFFECT OF PROXIMITY OF ALIEN MALES

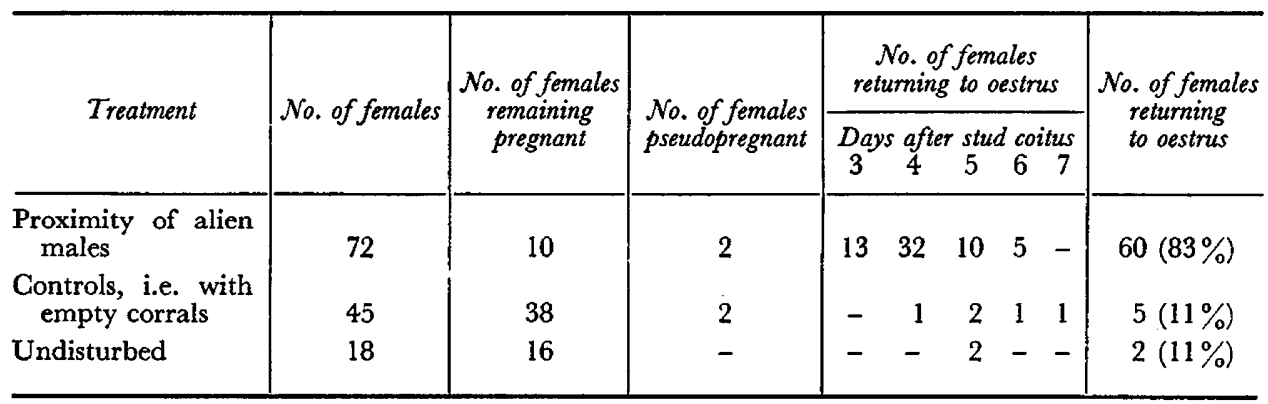

In addition to the specific controls proper to each experiment, some females had no change of housing after separation from the stud male (undisturbed). These served to indicate the expected level of spontaneous failure of pregnancy.

Vaginal smears were examined daily from all females up to Day 7 after mating. The reappearance of vaginal cornification during this period was taken to indicate a blocked pregnancy. The females were killed on Day 7 and the uteri examined for implantations. Females which had not returned to oestrus and had no implantation sites were assumed to be pseudopregnant. 


\title{
RESULTS
}

\section{The reaction}

\author{
EXPOSURE TO THE INTACT MALE (Table 1)
}

Recently-mated females were exposed to the proximity of an alien male, i.e. belonging to a different strain, which was confined within an expanded metal corral as illustrated (Pl. 1, Fig. 1). The female was then introduced into the box containing the male, she was thus within sight and sound of the male, but did not have any bodily contact with him. As control, a group of females was subjected to the same change of physical environment, i.e. they were housed singly in boxes with empty corrals, i.e. without the males.

More than $80 \%(60 / 72)$ females exposed to males failed to maintain pregnancy, of these $75 \%(45 / 60)$ returned to oestrus within 3 days of the introduction of the male. The change in physical conditions alone did not affect pregnancy.

TABLE 2

EFFECT OF FRESH URINE AND FAEGES OF ALIEN MALES

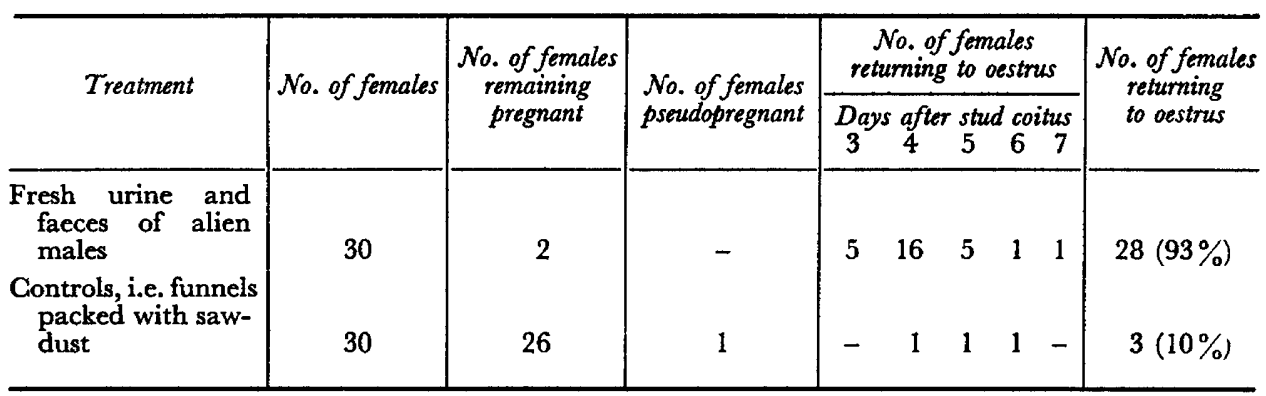

PREGNANCY-BLOCK IN THE ABSENGE OF THE MALE

Exposure to male urine and faeces (Table 2)

Each female was exposed to the excreta from twelve CBA males. The males were housed in a circular wire basket supported by a polythene funnel in such a way that their urine and faeces dropped into the box containing the females (Pl. 1, Fig. 2), by way of the tail of the funnel which penetrated into the box through a hole in the lid. The males had access to food and water and remained in the test situation for 3 days.

Pregnancy was also blocked in a high proportion, 93\% (28/30), of females exposed to male excreta. Again, 75\% (21/28) of females returned to oestrus within 3 days of the start of exposure.

Exposure to urine alone (Tables 3 and 4)

For this, the experimental arrangement was modified (Pl. 1, Fig. 3) in order to prevent faeces from entering the female's box. The tail of the funnel was raised about 3 in. above a circular hole in the lid of the box and a conical glass bulb with three equidistant longitudinal ridges was inserted in the hole. This arrangement allowed urine to drain into the box but caused faeces to 
bounce off and collect in a tray placed on the lid of the box. The males were provided with drinking water, but food was withdrawn from them during the period spent in the basket. The males in the basket were replaced every $12 \mathrm{hr}$. As control, females were exposed in the same test situation below a group of males but urine was prevented from entering their boxes by packing the funnel with sawdust.

Urine alone was equally effective in preventing implantation in the majority of females. Again oestrus returned within 3 days of exposure in $70 \%(30 / 43)$ of females in which pregnancy was blocked.

TABLE 3

EFFECT OF FRESH URINE OF ALIEN MALES

\begin{tabular}{|c|c|c|c|c|c|c|c|c|c|}
\hline \multirow{2}{*}{ Treatment } & \multirow{2}{*}{ No. of females } & \multirow{2}{*}{$\begin{array}{c}\text { No. of females } \\
\text { remaining } \\
\text { pregnant }\end{array}$} & \multirow{2}{*}{$\begin{array}{l}\text { No. of females } \\
\text { pseudopregnant }\end{array}$} & \multicolumn{5}{|c|}{$\begin{array}{l}\text { No. of females } \\
\text { returning to oestrus }\end{array}$} & \multirow{2}{*}{$\begin{array}{l}\text { No. of females } \\
\text { returming } \\
\text { to oestrus }\end{array}$} \\
\hline & & & & & s afte & 5 & & $\begin{array}{c}\text { tus } \\
7\end{array}$ & \\
\hline $\begin{array}{l}\text { Fresh urine of alien } \\
\text { males }\end{array}$ & 51 & 8 & - & 3 & 27 & 9 & 3 & 1 & $43(84 \%)$ \\
\hline $\begin{array}{l}\text { Controls, i.e. funnels } \\
\text { packed with saw- } \\
\text { dust }\end{array}$ & 51 & 43 & 3 & 1 & 1 & 2 & 1 & - & $5(10 \%)$ \\
\hline
\end{tabular}

TABLE 4

EFFECT OF FRESH URINE ON PSEUDOPREGNANT FEMALES

\begin{tabular}{|c|c|c|c|c|c|c|c|c|}
\hline \multirow{2}{*}{ Treatment } & \multirow{2}{*}{ No. of females } & \multirow{2}{*}{$\begin{array}{c}\text { No. of females } \\
\text { remaining } \\
\text { pseudopregnant }\end{array}$} & \multicolumn{5}{|c|}{$\begin{array}{c}\text { No. of females returning } \\
\text { to oestrus }\end{array}$} & \multirow{2}{*}{$\begin{array}{c}\text { No. of females } \\
\text { returning } \\
\text { to oestrus }\end{array}$} \\
\hline & & & \multicolumn{4}{|c|}{ Days after stud coitus } & 7 & \\
\hline Fresh urine of alien males & 54 & 6 & 8 & 30 & 8 & 2 & - & $48(89 \%)$ \\
\hline $\begin{array}{l}\text { Controls, i.e. funnels } \\
\text { packed with sawdust }\end{array}$ & 54 & 44 & - & 5 & 2 & 3 & - & $10(19 \%)$ \\
\hline Undisturbed & 10 & 8 & - & - & - & 2 & - & $2(20 \%)$ \\
\hline
\end{tabular}

This experiment was repeated using females rendered pseudopregnant by mating with a vasectomized male. Similar results were obtained (Table 4). Exposure to male urine prevented the development of the pseudopregnancy which normally follows sterile coitus.

\section{Topical application of urine (Table 5)}

A small drop of recently-collected male urine without any preservative was placed on the external nares of the test females three times a day (10.00 hours, 14.00 hours and 19.00 hours) for the 3 days of test, the females, as usual, being housed individually with cloth bedding during the test period. As control, a group of females received a similar application of a small drop of water. 
PLATE 1

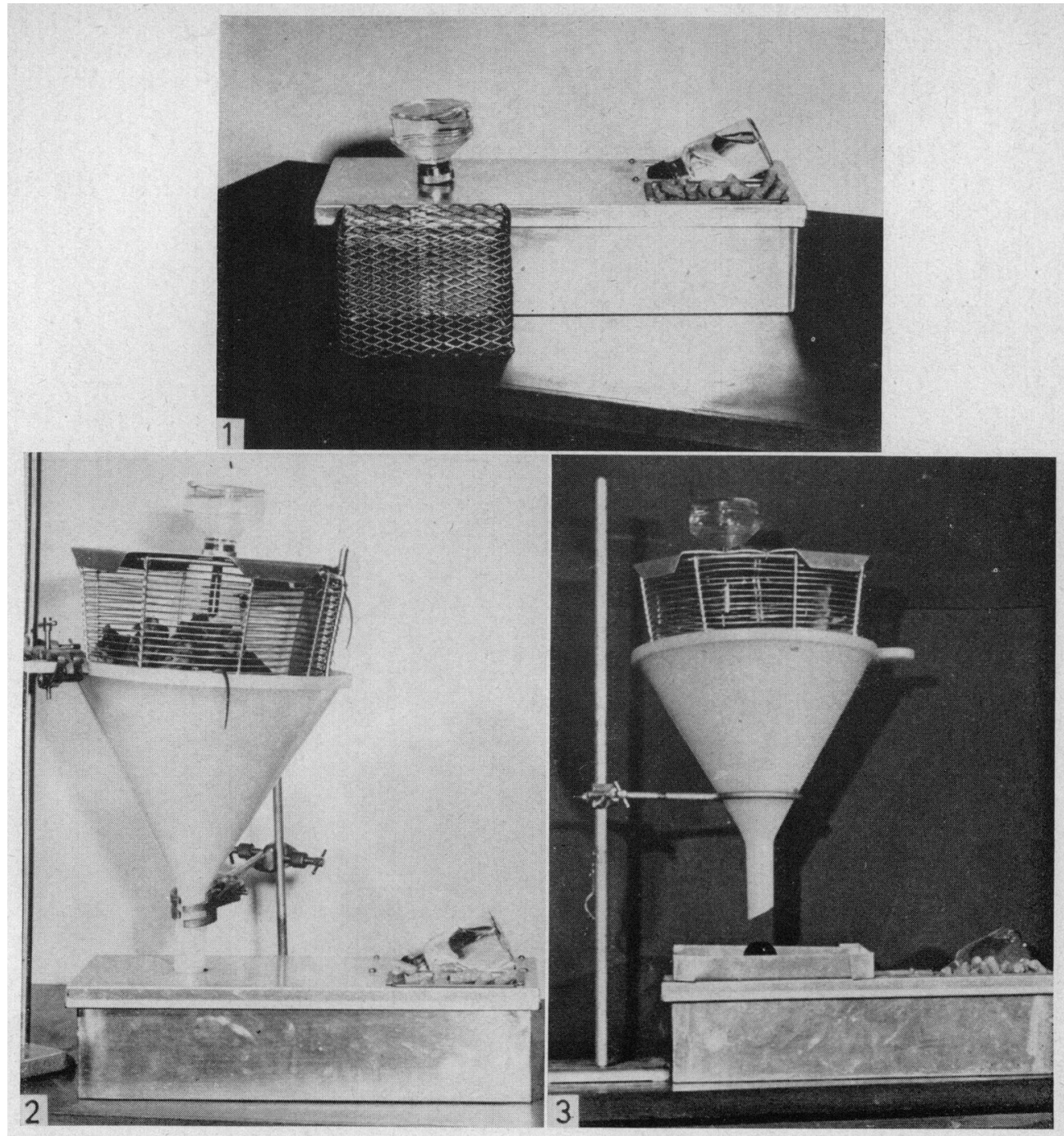

FIG. 1. The set-up used for exposing the newly mated $P$ female to the alien male. The male was confined in the metal corral inside the female's box. In the picture the corral is shown outside the box.

FIG. 2. The set-up used for exposing the newly mated female to the urine and faeces of alien males. The males were housed in the wire basket above supported by a polythene funnel. The tail of the funnel is introduced into the female's box through an aperture on the lid.

FIG. 3. The wire basket-polythene funnel arrangement used for exposing the mated female to fresh urine of alien males. On the lid of the female's box can be seen the conical glass bulb (black in colour) and the rectangular dish for collecting the faecal pellets. 
This procedure likewise caused pregnancy to fail in a high proportion of the females treated with urine. Tap water, applied locally, was without effect.

TABLE 5

EFFECT OF TOPICAL APPLICATION OF FRESH URINE OF ALIEN MALES

\begin{tabular}{|c|c|c|c|c|c|c|c|c|c|}
\hline \multirow{2}{*}{ Treatment } & \multirow{2}{*}{ No. of females } & \multirow{2}{*}{$\begin{array}{l}\text { No. of females } \\
\text { remaining } \\
\text { pregnant }\end{array}$} & \multirow{2}{*}{$\begin{array}{c}\text { No. of females } \\
\text { pseudo- } \\
\text { pregnant }\end{array}$} & \multicolumn{5}{|c|}{$\begin{array}{l}\text { No. of females } \\
\text { returning to oestrus }\end{array}$} & \multirow{2}{*}{$\begin{array}{c}\text { No. of females } \\
\text { returning } \\
\text { to oestrus }\end{array}$} \\
\hline & & & & 3 & $\begin{array}{l}D a \\
\text { stu } \\
4\end{array}$ & 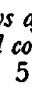 & $\begin{array}{l}\text { fter } \\
\text { tus } \\
6\end{array}$ & 7 & \\
\hline $\begin{array}{l}\text { Topical application of } \\
\text { fresh urine of alien } \\
\text { males }\end{array}$ & 50 & 8 & 5 & 3 & 25 & 2 & 4 & 1 & $37(74 \%)$ \\
\hline $\begin{array}{l}\text { Controls, i.e. topical } \\
\text { application of water }\end{array}$ & 50 & 35 & 10 & - & - & 3 & 1 & 1 & $5(10 \%)$ \\
\hline Undisturbed & 20 & 16 & 2 & - & - & - & 2 & 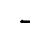 & $2(10 \%)$ \\
\hline
\end{tabular}

Effect of storage on pregnancy-blocking capacity of male urine

Urine from males was collected overnight in a mixture of antibiotics (penicillin, streptomycin and terramycin) and an antioxidant, Topanol A (Imperial Chemical Industries Ltd). A small glass beaker containing the preservative mixture was placed in the mouse box below the apex of the conical glass bulb so that the urine dropped directly into it. Urine collected in this way and containing about $1: 5$ by volume of preservative was frozen and stored from 1 to 7 days before use. When required for experiment the frozen urine was thawed at room temperature before being administered to the female.

TABLE 6

EFFECT OF TWICE DAILY APPLICATION OF STORED URINE

\begin{tabular}{|c|c|c|c|c|c|c|c|c|}
\hline \multirow{2}{*}{ Treatment } & \multirow{2}{*}{ No. of females } & \multirow{2}{*}{$\begin{array}{c}\text { No. of females } \\
\text { remaining } \\
\text { pregnant }\end{array}$} & \multirow{2}{*}{$\begin{array}{c}\text { No. of females } \\
\text { pseudo- } \\
\text { pregnant }\end{array}$} & \multicolumn{4}{|c|}{$\begin{array}{l}\text { No. of females } \\
\text { returning to oestrus }\end{array}$} & \multirow{2}{*}{$\begin{array}{l}\text { No. of females } \\
\text { returning } \\
\text { to oestrus }\end{array}$} \\
\hline & & & & $\begin{array}{l}\text { Days } a f \\
34\end{array}$ & ersth & $\begin{array}{ll}\text { ed co } \\
6\end{array}$ & $\begin{array}{c}\text { itus } \\
7\end{array}$ & \\
\hline $\begin{array}{l}\text { Stored urine of alien } \\
\text { males on cloth bed- } \\
\text { ding }\end{array}$ & 66 & 24 & - & $\begin{array}{ll}3 & 25\end{array}$ & 10 & 4 & - & $42(64 \%)$ \\
\hline $\begin{array}{l}\text { Controls, i.e. water on } \\
\text { cloth bedding }\end{array}$ & 66 & 50 & 9 & -5 & 1 & - & & $7(11 \%)$ \\
\hline Undisturbed & 10 & 9 & 1 & $-\quad-$ & - & - & - & - \\
\hline
\end{tabular}

Trice daily application of stored urine (Table 6)

The cloth bedding supplied during the test period was wetted twice daily ( 10.00 hours and 19.00 hours) with $3 \mathrm{ml}$ of stored urine. As control, the bedding of other females was wetted with $3 \mathrm{ml}$ of tap water.

Urine stored and applied in this way caused pregnancy to fail in $64 \%(42 / 66)$ of females, most of which, $70 \%(28 / 42)$, returned to oestrus within 3 days of the start of treatment. 
Exposure to a continuous drip of stored urine (Table 7)

The slightly lower response of females to stored urine compared with that to fresh urine, could reflect either a loss of potency on storage or a less efficient method of application than the continually renewed stimulus supplied by the males. Stored urine was therefore administered by an infusion apparatus (B 1831 Unita Continuous Infusion Apparatus manufactured by B. Braun, Apparatebau Melsingen, West Germany) which held six syringes simultaneously. Three of the syringes were filled with stored urine which was renewed twice daily, the remaining three syringes contained tap water. Polythene tubes connected the nozzles of the syringes to the boxes containing the females. Delivery was at the rate of $0.5 \mathrm{ml} / \mathrm{hr}$.

\section{TABLE 7}

EFFECT OF CONTINUOUS DRIP OF STORED URINE OF ALIEN MALES

\begin{tabular}{|c|c|c|c|c|c|c|c|c|c|}
\hline \multirow{2}{*}{ Treatment } & \multirow{2}{*}{ No. of females } & \multirow{2}{*}{$\begin{array}{c}\text { No. of females } \\
\text { remaining } \\
\text { pregnant }\end{array}$} & \multirow{2}{*}{$\begin{array}{c}\text { No. of females } \\
\text { pseudo- } \\
\text { pregnant }\end{array}$} & \multicolumn{5}{|c|}{$\begin{array}{l}\text { No. of females } \\
\text { rcturning to oestrus }\end{array}$} & \multirow{2}{*}{$\begin{array}{l}\text { No. of females } \\
\text { returning } \\
\text { to oestrus }\end{array}$} \\
\hline & & & & 3 & $\begin{array}{l}\text { Days } \\
\text { stud } \\
4\end{array}$ & $\begin{array}{l}\text { s af } \\
\text { coi } \\
5\end{array}$ & $\begin{aligned} \text { ter } \\
6\end{aligned}$ & 7 & \\
\hline $\begin{array}{l}\text { Continuous drip of } \\
\text { stored urine of alien } \\
\text { males }\end{array}$ & 52 & 23 & 1 & - & 19 & 8 & 1 & & $28(54 \%)$ \\
\hline $\begin{array}{l}\text { Controls, i.e. continu- } \\
\text { ous drip of water }\end{array}$ & 52 & 40 & 5 & - & 3 & 1 & 3 & - & $7(13 \%)$ \\
\hline Undisturbed & 17 & 15 & - & - & - & 1 & 1 & 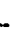 & $2(12 \%)$ \\
\hline
\end{tabular}

Under these conditions also, response to stored urine, 54\% (25/52) pregnancy failures, was lower than that to fresh urine, but there was no difference in the timing of the response. Among those females in which pregnancy was blocked, $68 \%(19 / 28)$ returned to oestrus within 3 days of the start of exposure.

\section{DISCUSSION}

The incidence of over $80 \%$ of pregnancy failures in females exposed to the fresh urine of alien males clearly indicates that urine is the immediate source of the pheromones causing failure of ovo-implantation in newly-mated mice. The fact that there is no apparent difference in the percentage of pregnancy failures in females exposed to alien males and in those exposed to the urine alone indicates that probably all the components of the odour spectrum involved in the pregnancy block are excreted in the urine of males.

Confirmatory evidence in favour of the male urine as the immediate source of the reproductive pheromones is provided by the capacity of stored urine to block the pregnancy of newly mated females. The lower incidence of pregnancy failures in females exposed to the stored urine may be due to the fact that the urine might have lost some of its potency by remaining at room temperature for several hours. Urine stored without preservatives is incapable of blocking the pregnancy of females (Parkes \& Bruce, 1961). During the course of the 
present investigations it was noticed that after about 7 days, even with preservatives, the stored and frozen urine of alien males progressively lost its potency and after about 2 weeks' storage it had no effect on newly mated females. The unstable nature of the reproductive pheromones of the male mouse is manifest in these experiments. Our experimental procedures necessitated the housing of the untreated control females close to the cages of test females which were being exposed to alien males or their urine. However, this did not interfere with the continuance of pregnancy in the vast majority of controls.

The fact that pregnancy block could be effected in newly mated females by topical application of less than $0.25 \mathrm{ml}$ of recently collected urine of alien males, three times a day, suggests that the pheromones can be effective in very small amounts. Pregnancy block cannot be augmented by increasing the number of males to which a female is exposed (mice: Bruce, 1963; Peromyscus: Bronson \& Eleftheriou, 1963). But the capacity to cause failure of ovo-implantation can be induced in spayed and androgenized females which indicates that the reproductive pheromones produced by male mice are either excretion products of androgens or secretions of some androgen-dependent gland (Dominic, 1965).

TABLE 8

SUMMARY OF TIME RELATIONS IN PREGNANGY FAILURE

\begin{tabular}{|c|c|c|c|c|c|c|c|}
\hline \multirow[b]{2}{*}{ Females } & \multirow{2}{*}{$\begin{array}{l}\text { No. of females in } \\
\text { which pregnancy failed }\end{array}$} & \multicolumn{5}{|c|}{ No. of females returning to oestrus } & \multirow{2}{*}{$\begin{array}{l}\text { Proportion returning } \\
\text { to oestrus within } 4 \\
\text { days of start of test }\end{array}$} \\
\hline & & 3 & $\underset{4}{D a y s}$ & $\begin{array}{l}r \sin \\
5\end{array}$ & $\begin{array}{l}6 \\
6\end{array}$ & 7 & \\
\hline $\begin{array}{l}\text { Exposed for Days } 1 \text { to } 3 \\
\text { To males } \\
\text { To male urine }\end{array}$ & $\begin{array}{r}60 \\
226\end{array}$ & $\begin{array}{l}13 \\
22\end{array}$ & $\begin{array}{r}32 \\
142\end{array}$ & $\begin{array}{l}10 \\
44\end{array}$ & $\begin{array}{r}5 \\
15\end{array}$ & $\overline{3}$ & $\begin{array}{l}91 \% \\
92 \%\end{array}$ \\
\hline $\begin{array}{l}\text { Sundry controls } \\
\text { Undisturbed }\end{array}$ & $\begin{array}{r}42 \\
8\end{array}$ & $\begin{array}{l}1 \\
0\end{array}$ & $\begin{array}{r}16 \\
0\end{array}$ & $\begin{array}{r}12 \\
3\end{array}$ & $\begin{array}{r}10 \\
5\end{array}$ & $\begin{array}{l}3 \\
0\end{array}$ & \} $64 \%$ \\
\hline
\end{tabular}

The time relations in the olfactory block to ovo-implantation are noteworthy. As originally pointed out by Bruce (1961) about $90 \%$ of the females in which pregnancy is blocked by exposure to males return to oestrus within 4 days of exposure with a peak (more than $50 \%$ ) on the 3rd day. This same time schedule is shown by the females in which the stimulus to pregnancy failure is provided by male urine (Table 8 ), a further indication that the same reaction is induced by both stimuli. This characteristic timing distinguishes the pregnancy failures due to olfactory stimulation by males from the spontaneous return of oestrus among control females. It also provides a further example of the accelerating influence of the male on oestrus which has been described for several species of mammals, e.g. sheep (Schinkel, 1954), goats (Shelton, 1960) and mice (Whitten, 1956, 1958).

\section{ACKNOWLEDGMENTS}

I am greatly indebted to Professor A. S. Parkes, C.B.E., F.R.s., for valuable suggestions and help at all stages of the work and to Miss Hilda M. Bruce for 
advice and critical reading of the manuscript. My thanks are due to Professor I. E. Bush for advice on the preservation of the urine of male mice and to Dr E. V. Hulse and Dr N. A. Mitchison for generous supply of CBA male mice. It is also a pleasure to thank Mr F. R. Lemmon for valuable technical assistance and Miss Margaret Glarke, Mrs Rozelle Shipp, Mrs Theo Moore and Mrs Kathleen McNicol for the care of the animals and laboratory assistance. The investigations were carried out during the tenure of a Population Council Fellowship and a Gulbenkian Studentship from Churchill College. Working expenses were defrayed from a grant to Professor Parkes by the Ford Foundation.

\section{REFERENCES}

Bronson, F. H. \& Eleftheriou, B. E. (1963) Influence of strange males on implantation in the deer mouse. Gen. comp. Endocr. 3, 515.

BRUCE, H. M. (1959) An exteroceptive block to pregnancy in the mouse. Nature, Lond. 184, 105.

BRUCE, H. M. (1960) A block to pregnancy in mice caused by the proximity of strange male. $\mathcal{F}$. Reprod. Fert. 1, 96.

BRUCE, H. M. (1961) Time relations in pregnancy block induced by strange males. F. Reprod. Fert. 2, 138.

Bruce, H. M. (1963) Olfactory block to pregnancy among grouped mice. F. Reprod. Fert. 6, 451.

BRUCE, H. M. \& PARRotr, D. V. M. (1960) Role of olfactory sense in pregnancy block induced by strange males. Science, N.Y. 131, 1526.

Dominic, G. J. (1964) Source of the male odour causing pregnancy block in mice. F. Reprod. Fert. 8, 266.

Dominı, C. J. (1965) The origin of the pheromones causing pregnancy block in mice. $\mathcal{F}$. Reprod. Fert. $10,469$.

Parkes, A. S. \& Bruce, H. M. (1961) Olfactory stimuli in mammalian reproduction. Science, N.X. 134, 1049.

Parkes, A. S. \& Bruce, H. M. (1962) Pregnancy block in mice placed in boxes soiled by males. 7. Reprod. Fert. 4, 303.

Schrnkel, P. G. (1954) The effect of the ram on the incidence and occurrence of oestrus in ewes. Aust. vet. 7. 30, 189.

Shelton, M. (1960) Influence of the presence of a male goat on the initiation of oestrus cycling and ovulation of the angora does. F. Anim. Sci. 19, 368.

WhITten, W. K. (1956) Modification of the oestrous cycle of the mouse by external stimuli associated with the male. $\mathcal{F}$. Endocr. 13, 399.

WhItTen, W. K. (1958) Modification of the oestrous cycle of the mouse by external stimuli associated with the male. Changes in the oestrous cycle as determined by vaginal smears. F. Endocr. 17, 307. 